\title{
Research on experimental teaching reform of human resource management course in Higher Vocational Colleges
}

\author{
Yingchao Bai \\ Heyuan Polytechnic, Heyuan, Guangdong, 517000, China \\ baiying168@163.com
}

Keywords: higher vocational education; human resources management; experimental teaching; reform research

\begin{abstract}
The strength and depth of experimental teaching still need to be strengthened in the teaching process of the source management course in higher vocational education due to the constraints of teachers, teaching system, teaching content and experimental conditions. In view of the problems in the experimental teaching of human resource management in higher vocational education, this paper proposes to introduce and train teachers to design and develop the experimental teaching of human resources. On the basis of making full use of relevant practical training to construct a multi-level training system of human resource management skills, the experimental teaching level of the management course of high vocational school personnel resource management is improved.
\end{abstract}

\section{Introduction}

The course of human resource management is a required course in economics and management specialty of higher vocational education. In the future, the students need some knowledge and skills of human resources management, whether they are going to the management posts in the grass-roots level or in the management of human resources. In this sense, the skills of human resource management are the general and necessary skills of the intention of management. However, the teaching of human resource management in higher vocational education is still based on traditional teaching. Although there are many kinds of teaching methods, there are still some shortcomings in the reform of experimental teaching. At the same time, the human resource management posts in the enterprise are usually limited and require work experience, which leads to a few higher vocational students who can engage in the work of human resource management in the enterprise. Therefore, in order to improve students' skills, higher vocational colleges still need to further intensify the implementation of experimental teaching reform of human resource management courses.

\section{Problems in experimental teaching of human resources management course in Higher Vocational Colleges}

\subsection{Teachers' strength is not matched with the requirements of experimental teaching}

More and more vocational colleges have equipped the simulation system for human resource management courses, and the training conditions have been greatly improved. However, there are few full-time human resources experimental teaching teachers in higher vocational colleges. And the advantage of this model is that teachers have a better understanding of the students' theoretical study and practical exercises, which are conducive to teaching students in accordance with their aptitude, lack of experimental teaching level is not professional, and the training depth of experimental training is not enough. At present, vocational colleges in China emphasize the cultivation of vocational skills while teachers still value academic qualifications. Such a personnel system leads to two results. On the one hand, the current human resources management course teachers' practical experience is not 
enough, and it does not match experimental teaching requirements. On the other hand, employees with abundant working experience but less educated are hard to enter higher vocational teaching teams, which limits the improvement of experimental and practical teaching level.

\subsection{The design of the course content and system is not pertinent}

In recent years, higher vocational colleges have made great efforts in teaching reform. Most of the courses have redesigned the curriculum system, reselected the content of teaching, and made great progress in the reform of teaching. However, the current teaching reform is mainly aimed at theoretical course teaching, while experimental training teaching is less studied. In particular, there is less research on the experimental teaching design of human resource management courses in higher vocational colleges, which limits the effectiveness of practical teaching.

\subsection{There are fewer experimental teaching platforms for the six sub modules of human resource management.}

At present, the teaching of the six sub modules of the human resource management course in higher vocational colleges is still dominated by traditional classroom, and the experimental teaching is seldom applied in the teaching process of each module. At the same time, the comprehensive training course of human resource management is trained by simulating the operation of the enterprise and integrating the various links of the human resource management, and then the evaluation and ranking of the operation effect and the operation effect of different modules of human resource management. Although this kind of training can make the students better understand the whole process of human resource management, it is difficult to meet the requirements of the real job because the training of each module is too simple. Especially human resources planning, recruitment management, training management, performance management, salary management and other modules, not only lack of appropriate teaching background and task materials, but also lack of specific platform for independent simulation. It is difficult to achieve a theoretical module after the end of a theoretical study to consolidate the knowledge and strengthen the knowledge and professional skills.

\section{Higher vocational colleges can start from the redesign of teachers and curriculum to improve the level of experimental teaching.}

\subsection{We should strengthen the training of full-time teachers and improve the conditions for teachers to introduce.}

Higher vocational colleges should strengthen communication with relevant competent departments so as to achieve the goal of talent introduction with ability as the main consideration. In particular, the introduction of experimental and practical teachers should focus on the experience of human resource management in senior enterprises. The introduced teachers should have the ability to design and implement the recruitment management, performance assessment, salary management, training management and other modules, and strive to introduce talents with good practical teaching ability into the experimental teaching team.

\subsection{Redesign of curriculum system and content of human resource management}

If the students are engaged in the work of personnel resources after graduation, they are generally the primary management posts, and the scope of the work is mainly the implementation and coordination of human policies and systems. Therefore, the students need to have higher practical and practical ability. This requires that the teaching design of the curriculum system of human resources management in higher vocational colleges should take into consideration both theoretical knowledge and practical training. Based on this, we should pay attention to practicality in the selection of curriculum content of human resources management in higher vocational colleges. For example, it is possible to collect, screen and revise suitable training tasks from cooperative enterprises, and focus 
on refining the background and requirements of project tasks. In order to make the task background fully understood by the students without working experience, we should pay attention to the operability and high imitation of the teaching practice.

4. Higher vocational colleges should take part in the development and design of pre participation subsystem to improve the pertinence and applicability of the experimental teaching platform.

The human resources management course is generally divided into six modules, such as human resource planning, recruitment management, training management, performance management, salary management, labor relations management and so on. And there is a lack of training platform for each sub module at present. Under this background, it is suggested that the experimental teaching system and content of each sub module should be jointly designed by higher vocational human resource management teachers and cooperative enterprises. Then, the teachers of human resources management in higher vocational education make clear their development needs and seek the training platform of software system developers to cooperate to develop different modules, so as to realize the targeted simulation training system in all human resource management modules. For example, the human resource planning module can cooperate with enterprises to design human resource planning simulation system according to the requirements of manufacturing and service industries, which can meet the practical skills training of specific modules and adapt to the differences in different industries.

\section{Higher vocational colleges should make use of the existing training system to build a} multi-level simulation training system for human resource management skills.

\subsection{Sharing various teaching methods and building up knowledge of human resources management at basic level}

In the traditional classroom learning of human resource management, teachers should select specific project tasks and teaching contents based on the real job tasks of the enterprise. Teachers use various teaching methods, such as case analysis, scenario simulation, role playing, and practice, and actively explore mixed classroom teaching mode. For example, using various internet teaching platforms, especially the mobile internet teaching platform, to diversify the teaching field, teaching practice and teaching means, so that the students can make full use of the fragmentation time and improve the teaching effect of the traditional classroom.

5.2 Excavate the potential of enterprise training sand table training course, and do well in manpower training at the primary level.

Enterprise operation sand table simulation training is a primary simulation training course for economics and management majors. Although the course involves less specific human resource management skills, it can focus on the training of the team building, organizational division, daily operation management and team coordination required for the students. And these abilities are not only the comprehensive skills of the grassroots managers, but also the basic skills of human resource management.

5.3 Pay attention to human resources management simulation sand table training, do a good job in intermediate level manpower professional skills training.

The training of simulated sand table for human resource management in higher vocational colleges is usually based on a simulation system platform, which usually includes the whole workflow of human resource management, and is antagonistic while training the skills of human resource management. Therefore, this platform helps students grasp the whole process of human resource management, improve the interest of training, and stimulate students' enterprising spirit. But this platform also has the shortcoming that it is difficult to thoroughly carry out targeted training of 
various sub modules of human resource management. Based on this, in the training of simulated sand table of human resource management in higher vocational education, it is suggested that the training teachers can expand the background information and content of the actual training cases on the basis of the existing simulation, and integrate the characteristics and requirements of the common manufacturing enterprises and service enterprises. Besides, we should pay attention to the collection, processing and checking ability of training data plan, and timely comment on the problems found by students, so as to improve the effect of comprehensive training.

\subsection{Making full use of the comprehensive training platform of economics and management, and doing a comprehensive training of high-level human resource management skills}

It is suggested that the professional training of interdisciplinary skills should be set up in the specialty of Higher Vocational Colleges and universities. And the practical training combines the joint development of human resource management, enterprise management, marketing, logistics management, accounting and other specialties. The training not only simulates the establishment of production, marketing, human resources, finance and other departments within the enterprise, but also simulates the establishment of external organizations such as suppliers, customers and talent exchange centers, which highly restore the daily operation and management activities of the enterprises. Therefore, while training the students' professional skills, they are more trained to communicate and coordinate the internal departments, which are difficult to train in the conventional teaching, and communicate with the external organizations to negotiate and negotiate the basic ability.

The training of human resource management skills in higher vocational education should make full use of the cross professional comprehensive skills training platform to improve the students' comprehensive skills in human resource management. For example, in practical training, students are required to formulate corresponding work instructions and other rules and regulations according to the actual situation of enterprises, so as to train students' writing ability. At the same time, according to the specific management plan of the enterprise, the plan of human resource planning is formulated to train the students to effectively combine the management of human resources with the overall management of the enterprise.

\section{Acknowledgements}

This work was financially supported by the project of Educational Science Planning in Guangdong” Research and Exploration on the practice teaching mode of economics and management-Improving students' comprehensive ability based on multi-level virtual simulation training”(2017GGXJK064)

\section{References}

[1] Zhu Feng. On human resources management professional experimental course design [J]. Journal of Jilin Province Economic Management Cadre College, 2016, 26(6):74-76.

[2] Zeng Yan. Research on the construction of experimental teaching system in human resource management specialty [J]. Journal of Hubei University of Science and Technology, 2013, 33(3):179-180.

[3] Zhang Xia,Hu Jianyuan. The experimental teaching research design of professional core course of the human resource management[J]. Research and Exploration in Laboratory, 2016, 35(11):179-185.

[4] Wang Fuxiang. Construction of experimental teaching system for human resource management [J]. Journal of Langfang Teachers College (Natural Science Edition), 2012, 12(1):107-109.

[5] Zhang Xia. Innovative design and practice of research experiment teaching in human resource management major--Taking compensation management course as an example [J]. Experimental Technology and Management, 2013, 30(8):135-137. 